\title{
A Moyers-féle vegyes fogazati analízis alkalmazhatóságának vizsgálata a magyarországi lakosság körében
}

\author{
Pintér Zsófia dr. ${ }^{1^{*}}$ - Rill Leila dr. ${ }^{1^{*}}$ - Vitályos Géza dr. ${ }^{2}$ \\ Borbásné Farkas Kornélia dr. ${ }^{3}$ - Kolarovszki Béla dr. ${ }^{4}$ - Frank Dorottya dr. ${ }^{1}$
}

\author{
${ }^{1}$ Pécsi Tudományegyetem, Klinikai Központ, Fogászati és Szájsebészeti Klinika, Fogszabályozási Részleg, Pécs \\ ${ }^{2}$ Debreceni Egyetem, Fogorvostudományi Kar, Fogszabályozás Tanszék, Debrecen \\ ${ }^{3}$ Pécsi Tudományegyetem, Általános Orvostudományi Kar, Bioanalitikai Intézet, Pécs \\ ${ }^{4}$ Pécsi Tudományegyetem, Klinikai Központ, Fogászati és Szájsebészeti Klinika, Röntgen Diagnosztikai Részleg,
} Pécs

\begin{abstract}
Bevezetés: A Moyers-féle vegyes fogazati analízis az egyik leggyakrabban használt predikciós módszer, melynek segítségével meghatározhatjuk az elő nem tört fogak méretét, így még vegyes fogazati időszakban informálódhatunk a helyviszonyokról. Mivel azonban a fogméretek az egyes etnikai csoportok közt jelentősen eltérhetnek, ahhoz, hogy a helyhiány súlyosságát a lehető legpontosabban tudjuk meghatározni, külön a vizsgált egyén saját etnikai csoportjára vonatkoztatott módszert lenne optimális alkalmazni.

Célkitüzés: Célunk, hogy megvizsgáljuk, a Moyers-féle vegyes fogazati analízis mennyire pontosan használható Magyarországon.

Módszer: 370 páciens alginátlenyomat alapján készült alsó és felső gipszmintája került kiértékelésre. Pittsburgh digitális tolómérő segítségével határoztuk meg az egyes fogak mesiodistalis szélességét. A kapott értékekből számoltuk ki egyrészt a fogak valós, másrészt a Moyers-féle predikciós táblázat segítségével a várható helyigényét, majd a két értéket összevetettük.

Eredmények: Moyers-féle analízist használva minden viszonylatban, mindkét nem esetén szignifikáns különbséget találtunk az általunk mért valós és prediktív értékek között. A felső állcsonton férfiak esetében a 95\%-os, 85\%-os, $75 \%$-os és 65\%-os percentilisértékek is túlbecsülték az általunk mért értékeket, míg nők esetében csak a $65 \%$-os becsülte alá azt. Az alsó állcsont esetén mindegyik percentilisérték túlbecsülte a valós mérések eredményeit. Következtetések: Eredményeink alapján a Moyers-féle vegyes fogazati predikciós módszer nem alkalmazható megbízhatóan a magyar lakosságnál. Amennyiben használjuk, javasolt a klinikumban elterjedt $75 \%$ percentilisérték helyett inkább a 65\%-os adat alkalmazása, mivel ezzel a valós helyigényhez közelebbi eredményt kaphatunk.

Orv Hetil. 2019; 160(50): 1984-1989.
\end{abstract}

Kulcsszavak: vegyes fogazati analízis, Moyers-analízis, helyviszony-meghatározás

\section{Applicability of the Moyers mixed dentition analysis for the Hungarian population}

Introduction: Moyers mixed dentition analysis is one of the most commonly used prediction methods to estimate the size of the unerupted teeth. By its use, we can determine the severity of tooth size-arch length discrepancies in mixed dentition. Since the tooth size may vary considerably among different ethnic groups, for the most precise estimation of the required space, an analysis based on the individual's own ethnic group would be recommended.

Aim: Our aim was to evaluate the applicability of Moyers mixed dentition analysis for the Hungarian population. Method: Upper and lower study casts of 370 patients were evaluated. The mesiodistal widths of the teeth were measured by using a Pittsburgh digital caliper. The odontometric values obtained were used to calculate actual and predicted values. The actual teeth measurements were then statistically compared to the predicted values derived from Moyers probability tables. 
Results: Using Moyers analysis, we found significant differences at each percentile between the actual and predictive values in both sexes. In the upper jaw, values for men at the 95th, 85th, 75th, and 65 th percentile overestimated the actual values, while for women only the 65 th percentile underestimated it. In the lower jaw, all values were overestimated in relation to the actual measurements at all percentiles.

Conclusions: Based on our results, Moyers mixed dentition analysis cannot be reliably applied for the Hungarian population. If used, it is recommended to use the Moyers predicted values at the 65 th instead of the 75 th percentile, as this will result in closer estimation to the actual space requirements.

Keywords: mixed dentition space analysis, Moyers mixed dentition analysis, tooth size-arch length discrepancy

Pintér Zs, Rill L, Vitályos G, Borbásné Farkas K, Kolarovszki B, Frank D. [Applicability of the Moyers mixed dentition analysis for the Hungarian population]. Orv Hetil. 2019; 160(50): 1984-1989.

(Beérkezett: 2019. július 2.; elfogadva: 2019. augusztus 5.)

Az ortodonciai anomáliák korai felismerése és azok korai kezelése sok esetben lerövidítheti, megkönnyítheti, avagy bizonyos esetekben akár teljes mértékben szükségtelenné teheti a későbbi fogszabályozó kezelést. A fogazati rendellenességek közül a torlódás az egyik leggyakrabban előforduló anomália $[1,2]$. Torlódással akkor kell számolnunk, ha a fogak számára szükséges hely nem elegendő a fogívben [3], vagyis a szükséges hely és a rendelkezésre álló hely között diszkrepancia van [4]. Torlódás az esetek jelentős részében már a korai vegyes fogazatban látható [5]. A korai vegyes fogazati időszakban a rendelkezésre álló hely adott ugyan, és mérete egyszerüen meghatározható, azonban az elő nem tört maradó fogak pontos mérete és ennek megfelelően helyigénye már jelentős nehézségekbe ütközik. Többféle diagnosztikai vizsgálat áll rendelkezésünkre a még elő nem tört fogak (szemfogak és praemolarisok) mesiodistalis átmérőjének mérésére vegyes fogazatban, úgymint radiológiai és nem radiológiai módszerek. Bár a radiológiai analízisek legnagyobb előnye, hogy segítségükkel pontosan, egyénre szabottan mérhetôk az egyes fogak méretei, azonban extra sugárterheléssel járnak, és a sugárvédelmi előírásokat szem előtt tartva kizárólag ezen indikációval elvégezni nem javasoltak [6]. Így kidolgoztak úgynevezett nem radiológiai, vegyes fogazati predikciós módszereket, regressziós egyenleteket (Moyers [7], TanakaJohnston [8], Gross-Hasund [9], Bachmann [10], Tränkmann [11], Legovic [12]), melyek segítségével előre jelezhetjük a még elő nem tört fogak várható méretét. Ezen analízisek a már áttört fogak méretéből következtetnek a fogívben várható helyigényre. Ezáltal a rendelkezésre álló hely ismeretében a predikciós módszerek segítségével még a fogak áttörése előtt képet kaphatunk az esetlegesen várható helyviszonyokról. Minthogy a fogívek vegyes fogazatból maradó fogazatba történő fejlődése során általában a fogívekben a fogív hosszcsökkenése történik [13, 14], ezen analízisek használata elengedhetetlen a korai diagnózis felállításához, vagyis segítségükkel informálódunk az esetlegesen fennálló helyhiány mértékéről, így idejében dönthetünk preventív vagy interceptív beavatkozások szükségességéről;
Hotz-féle sorozatextrakció, irányított erupció, helyfenntartás, résnyitás vagy egyszerü obszerváció $[15,16]$.

$\mathrm{Az}$ említett predikciós módszereket azonban eltérő, elsősorban észak-amerikai és germán populációra dolgozták ki [7-12]. Mivel azonban a fogméretek az egyes etnikai csoportok közt jelentősen eltérhetnek [17-24], ahhoz, hogy a helyhiány súlyosságát a lehető legpontosabban tudjuk meghatározni, külön a vizsgált egyén saját etnikai csoportjára vonatkoztatott módszert lenne optimális alkalmazni. Továbbá vizsgálatok arra is rámutattak, hogy a fogak mérete generációról generációra folyamatosan növekvő tendenciát mutat az egész világon [2527].

Mindezek alapján a jelen vizsgálatunk célja, hogy megvizsgáljuk, mennyire pontosan és megbízhatóan lehet alkalmazni Magyarországon a klinikai gyakorlatban a leggyakrabban és elfogadottan használt Moyers-féle predikciós módszert.

\section{Módszer}

Vizsgálatunkhoz a 2008 és 2016 között a Pécsi Tudományegyetem Fogászati és Szájsebészeti Klinikájának Fogszabályozási Részlegén, illetve a Debreceni Tudományegyetem Fogorvostudományi Karának Gyermekfogászati és Fogszabályozási Tanszékén kezelt páciensek ortodonciai kezelés előtt készített alsó és felső gipszmintáit használtuk. A minták a következő kritériumok alapján kerültek kiválasztásra:

1. magyar, illetve magyar felmenőkkel rendelkező páciensek;

2. teljesen előtört maradó fogazat mindkét fogívben, eltekintve a második és harmadik molarisoktól;

3. 9 és 20 év közötti páciensek mintái, kiküszöbölve így a fogaknak a kor elörehaladtával létrejövő esetleges interproximális méretcsökkenését [28, 29];

4. sértetlen, jó minőségű gipszminta;

5. fogszabályozó kezelés előtti minták, kiküszöbölve a kezelés során alkalmazott interproximális redukciót;

6. alaki és számbeli rendellenességtől, approximális restaurációktól és laesióktól mentes fogazat. 
A vizsgált páciensek nem és életkor szerinti megoszlása (átlag standard deviáció $[\mathrm{SD}])$

\begin{tabular}{llrrr}
\hline & Nem & Mintaszám & Korosztály & Átlagéletkor \pm SD \\
\hline $\begin{array}{llrr}\text { Pécsi Tudomány- } \\
\text { egyetem }\end{array}$ & Férfi & 63 & $13-20$ & $14,41 \pm 2,106$ \\
& Nó & 67 & $11-19$ & $14,83 \pm 2,115$ \\
\hline $\begin{array}{l}\text { Debreceni } \\
\text { Egyetem }\end{array}$ & Férfi & 81 & $11-18$ & $14,29 \pm 1,145$ \\
& Nő & 159 & $9-19$ & $14,09 \pm 2,209$ \\
\hline
\end{tabular}

A kritériumoknak összesen 370 páciens alginátlenyomat alapján készült gipszmintája felelt meg. A kiértékelésre került mintákhoz tartozó páciensek nem és életkor szerinti megoszlását az 1 . táblázat szemlélteti. A vizsgálatokat a Debreceni Egyetem Orvos- és Egészségtudományi Centruma Regionális és Intézményi Kutatásetikai Bizottságának (DE RKEB/IKEB 4545-2016), illetve a Pécsi Tudományegyetem Klinikai Központja Adatvédelmi, Esélyegyenlőségi és Koordinációs Osztályának az egészségügyi adatok gyúijtésére, kezelésére és védelmére vonatkozó engedélyével végeztük. A mérések Pittsburgh digitális tolómérővel (Harbor Freight Tools, Calabasas, CA, Amerikai Egyesült Államok [USA]) történtek, mely $0,01 \mathrm{~mm}$-es leolvasási pontossággal rendelkezik. A digitális technika alkalmazásával elkerülhetők a fényviszonyokból és a szem fáradtságából eredő félreolvasások [30]. A vizsgálat során egyenként mértük meg mind a négy kvadráns középső és laterális metszőjének, szemfogának, első és második praemolarisának mesiodistalis szélességét. A fogak méréséhez a Hunter és Priest által használt módszert alkalmaztunk [31]. Röviden, a fogak legnagyobb mesiodistalis átmérőjének lemérésére a tolóméró pofáit labiális irányból helyeztük fel a fogak klinikai koronájának hossztengelyére merőlegesen, az okkluzális síkkal párhuzamosan, a vizsgált fog approximális felszíneire, a kontaktpontok elé. Amennyiben torlódás vagy egyéb helyzeti rendellenesség miatt ez nem volt megvalósítható, a pofákat incizális, illetve okkluzális irányból, lingvoverzió esetén pedig lingvális irányból helyeztük fel. Ha a fog rotálódott volt, a normális helyzetében létrejövő kontaktpontokat vettük figyelembe. Ezt követően a fogak valós helyigényét a szemfogak, az első és második praemolarisok mesiodistalis átmérójének kvadránsonkénti összegéből számoltuk ki. A várható prediktív adatokat pedig a mandibularis négy metszố mesiodistalis átmérőjének összege alapján Moyers predikciós táblázataiból [7] olvastuk ki, melyeket az ott feltüntetett 95\%-os, 85\%-os, 75\%-os és 65\%-os percentilisértékeknek megfelelően vizsgáltuk.

A statisztikai kiértékeléseket az SPSS 20.0 programmal végeztük (IBM Corporation, Chicago, IL, USA). Páros t-próba segítségével hasonlítottuk össze az általunk mért valós és a Moyers-féle analízis által meghatározott prediktív eredmények közötti különbségeket. A fogak helyigénye nemek szerinti eltérésének meghatározása független mintás t-próba segítségével történt. A mérések megbízhatóságának ellenőrzésére „intraobserver reliabil-

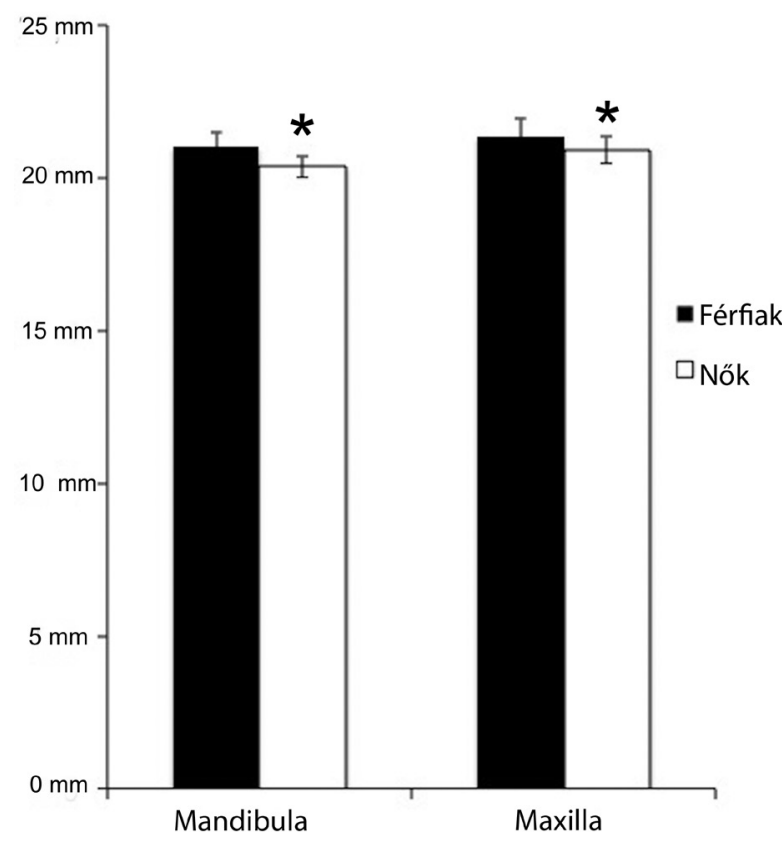

1. ábra $\mid$ Szemfogak és praemolarisok együttes helyigényének átlaga \pm standard deviációja (SD) férfiak és nók esetén ( ${ }^{*} \mathrm{p}<0.05$ vs. kontroll)

ity" tesztet alkalmaztunk intraklassz korrelációs koefficiens számolással, mely 40 , véletlenszerúen kiválasztott minta újbóli mérése alapján történt. A szignifikanciaszintet a $\mathrm{p}<0,05$ szinten határoztuk meg.

\section{Eredmények}

\section{A vizsgáló mérésének megbizhatósága}

A mérések megbízhatóságának meghatározása során az intraklassz korrelációs koefficiens ( $\mathrm{r}$ ) 0,908 lett, ami kiváló mérési pontosságot, reprodukálhatóságot jelent.

\section{A fogak méretének nemek szerinti összehasonlitása}

A szemfogak és praemolarisok együttes helyigénye a felső és az alsó állcsont esetén is szignifikánsan eltért a két nem esetében. A férfiaknál a nőkhöz képest a mandibula esetén átlagosan mintegy $0,6 \mathrm{~mm}$-rel, a maxillánál pedig $0,5 \mathrm{~mm}$-rel nagyobb a szemfogak és kisőrlők együttes mesiodistalis szélessége ( 1 ábra). Emiatt indokolt a magyarországi lakosság tekintetében is a külön, nemek szerinti helyigény-meghatározás.

\section{A Moyers-féle vegyes fogazati analizis alkalmazhatósága a magyar lakosság tekintetében}

A Moyers-féle predikciós táblázat alapján minden vizsgált viszonylatban, mindkét nem esetén statisztikailag szignifikáns különbséget találtunk az általunk mért valós 


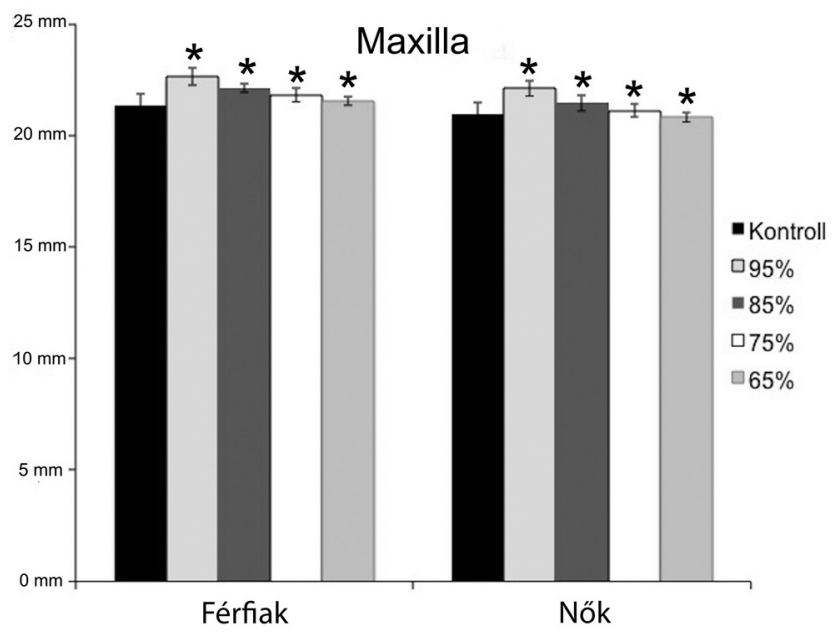

2. ábra

A felső állcsonton a szemfogak és praemolarisok együttes helyigényének az általunk mért valós (kontroll) és a Moyers-féle vegyes fogazati analízissel meghatározott prediktív értékeinek (átlag $\pm \mathrm{SD})$ összehasonlítása férfiak és nók esetén $\left({ }^{*} \mathrm{p}<0.05\right.$ vs kontroll)

és prediktív értékek között. A felső állcsonton (2. ábra) a férfiaknál az összes percentilisérték szignifikánsan túlbecsülte az általunk mért valós mesiodistalis szélességeket. 95\% esetén átlagban kvadránsokként 1,25 mm-rel, $85 \%$-nál pedig $0,75 \mathrm{~mm}$-rel túlbecsült értékeket kaptunk. A mindennapi klinikai gyakorlatban alkalmazott $75 \%$ percentilisadatnál az egész állcsontra vonatkoztatva 2,6 mm-rel nagyobb értéket mutatott a táblázat, mint amennyi az általunk mért tényleges helyigény volt. A legközelebbi valós és várható értékeket a $65 \%$ alkalmazása esetén kaptuk. Ezzel szemben a nőknél csak a 95\%-os, $85 \%$-os és $75 \%$-os szint becsülte túl, míg a $65 \%$-os percentilisérték alábecsülte a valós értékeket a maxilla fogait tekintve. A 95\% esetén 1,16 mm-rel, a 85\%-nál pedig 0,5 mm-rel nagyobb értéket adott kvadránsokként, mint a valós fogméretek. A 75\%-os percentilisadat pontosabb volt ugyan, mint a férfiaknál, de még így is szignifikánsan nagyobb eredményt adott a valós értékekhez képest, mivel mintegy 2,28 mm-rel túlbecsülte az általunk mért értékeket. A 65\%, bár a legközelebbi értéket adta, volt az egyetlen, amely alábecsülte a valós helyigényt.

$\mathrm{Az}$ alsó állcsontot vizsgálva mind férfiak, mind nők esetén az összes vizsgált percentilisszint túlbecsülte a valós helyigényt, valamint sokkal pontatlanabbul becsült, mint a felsó állcsont esetén (3. ábra). Átlagosan a férfiaknál a 95\%-os 1,86 mm-rel, a 85\%-os 1,12 mm-rel, a 75\%os pedig $0,68 \mathrm{~mm}$-rel nagyobb értékeket adott, mint az általunk mért értékek. Ezek az értékek kvadránsokra vonatkoznak, ezért a kétszeresük adja meg az egy állcsontra vonatkozó differenciát. Itt is a $65 \%$-os percentilis használatával kaptuk a legpontosabb értéket, oldalanként csak $0,35 \mathrm{~mm}$-rel becsülte túl a valós helyigényt. Nók esetében az alsó állcsonton oldalanként a 95\%-os percentilisadat $1,71 \mathrm{~mm}$-rel, míg a $85 \%$-os $0,98 \mathrm{~mm}$-rel nagyobb értéket adott, mint az általunk mért helyigény. A klinikumban alkalmazott $75 \%$ esetén a várható hely a

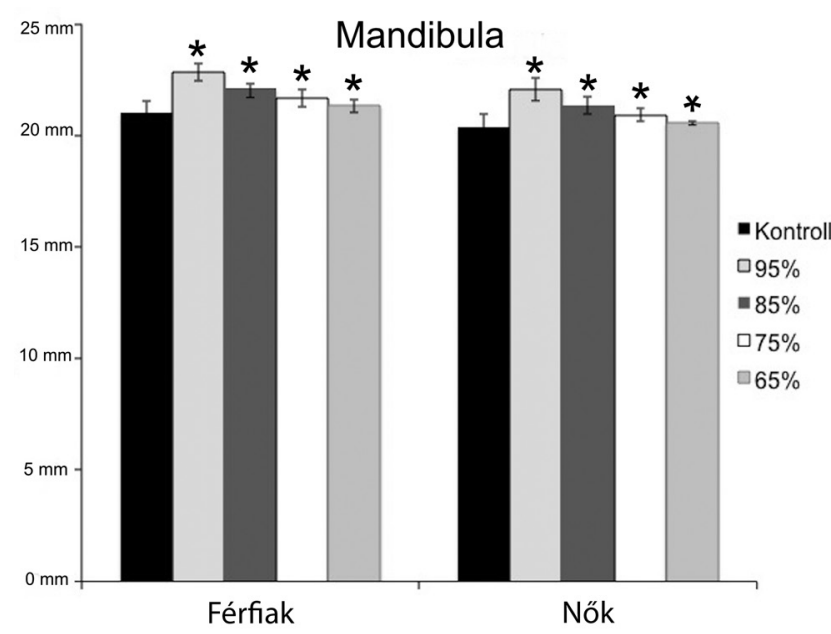

3. ábra $\quad$ Az alsó állcsonton a szemfogak és praemolarisok együttes hely igényének az általunk mért valós (kontroll) és a Moyers-féle vegyes fogazati analízissel meghatározott prediktív értékeinek (átlag \pm SD) összehasonlítása férfiak és nók esetén ( ${ }^{*} \mathrm{p}<0.05$ vs. kontroll)

mandibulára vetítve átlagosan mintegy $3 \mathrm{~mm}$-rel volt nagyobb, mint a fogak által ténylegesen elfoglalt hely. A 65\%-os percentilisérték alkalmazásával kaptuk a valósághoz legközelebb álló számokat, kvadránsonként átlagosan $0,56 \mathrm{~mm}$-rel becsülte túl azokat.

\section{Megbeszélés}

Vegyes fogazati modellanalízis során sokszor olyan fogak helyigényéról kell információt szereznünk, amelyek még nincsenek a szájban. A leggyakrabban ezen fogak várható méretigényét különböző predikciós módszerekkel határozzuk meg. A klinikumban a leggyakrabban alkalmazott Moyers-féle predikciós analízist észak-amerikai populáción fejlesztették ki [7], azonban bizonyított, hogy a fogak mérete az etnikai háttérrel szoros összefüggésben van [17-24]. Továbbá Buwembo és Luboga metaanalízisükben is arra a következtetésre jutottak, hogy a Moyersféle predikciós módszert nem lehet univerzálisan alkalmazni, ezért populációspecifikus módszerek kidolgozását és alkalmazását javasolják [32].

Mivel hazánkban ez idáig nem vizsgálták a Moyersféle predikciós módszer megbízhatóságát, célunk az volt, hogy meghatározzuk, vajon az mennyire pontosan használható a magyarországi lakosságra vetítve.

Másokhoz hasonlóan a fogak méretét tekintve hazánkban is szexuális dimorfizmust találtunk $[12,20,23$, 33-35], vagyis a szemfogak és a praemolarisok együttes helyigénye a felső és az alsó állcsont esetén is szignifikánsan eltért a két nem esetében. Ezek alapján tehát elmondhatjuk, hogy a magyar populációban sem vonhatók össze a nemek szerinti különböző helyigények. Továbbá eredményeink azt mutatták, hogy a Moyers-féle vegyes fogazati analízis általi predikciós értékek mindkét nem esetén statisztikailag szignifikánsan különböztek az álta- 
lunk mért valós méretektől. Egyetlen esetet, nőknél a 65\%-os percentilisértéket kivéve, mindkét állcsont tekintetében a Moyers-táblázat által meghatározott értékek minden percentilisszinten, mind a férfiaknál, mind a nőknél, szignifikánsan túlbecsülték a valós helyigényeket. Eredményeink nagyban megegyeznek a más szerzők által kapott következtetésekkel. A földrajzilag hozzánk legközelebbi, horvát lakosságon Legovic és mtsai azt találták, hogy a Moyers-féle predikciós módszer túlbecsüli a valós értékeket [36]. Dasgupta és Zahir bengáli populáción vizsgálta a Moyers, valamint a Tanaka és Johnston által kifejlesztett váltófogazati analízist. Eredményeik a mi vizsgálatunkkal nagymértékben összhangban állnak. Mindkét módszer túlbecsülte a valós helyigényt, és a Moyers-analízis az ugyancsak 65\%-os percentilist alkalmazva adta a valóshoz legközelebbi eredményt [37]. Maláj lakosságon végzett vizsgálatok szerint pedig a Moyers-analízis még az 50\%-os percentilis esetén is túlbecsült adatokat adott a mért, valós értékekhez képest [38]. Nigériai populáción vizsgálódva azt találták, hogy Tanaka és Johnston egyenlete mindkét nemben alábecsülte a valós értékeket, míg Moyers analízise férfiakon, a 85\%-os szintet alkalmazva pontos eredményeket adott [39]. Ezzel szemben mind az indiaiakat [40], mind a fekete dél-afrikaiakat vizsgálva arra jutottak, hogy az amerikaiakon kifejlesztett módszer - bár ugyancsak nem mutatkozott alkalmasnak azokon a területeken - a valós helyigénynél inkább kisebb értékeket ad, illetve ez utóbbi népcsoport esetén pontosabb becslést kaptak, ha Moyers analízisét a 75\%-osnál nagyobb percentilisszinten alkalmazták [41]. Egyedül a spanyolokat vizsgálva jutottak Paredes és mtsai arra a következtetésre, hogy a Moyers által is javasolt $75 \%$-os percentilis a mandibulán alkalmazva mind férfiakban, mind nókben pontosan becsülte a fogak helyigényét [42].

\section{Következtetés}

Kutatásunk alapján elmondhatjuk, hogy magyar lakosság esetén a klinikumban elterjedt 75\%-os percentilisérték helyett javasoljuk inkább a $65 \%$-os percentilis alkalmazását, mivel ebben az esetben kaphatunk a valós értékekhez legközelebbi eredményt. További célunk, hogy más ismertebb predikciós módszer megbízhatóságát is megvizsgáljuk, valamint ha szükséges, kidolgozzunk egy hazánkban pontosan használható analízist.

Anyagi támogatás: A közlemény megírása, illetve a kapcsolódó kutatómunka anyagi támogatásban nem részesült.

Szerzői munkamegosztás: A dolgozat a hat szerző közös munkája (P. Zs.: a minták mérése, P. Zs., V. G.: mintagyưjtés; R. L., V. G., B. F. K.: adatrendezés, adatelem- zés, R. L., F. D., K. B.: vizsgálati protokoll kidolgozása, irodalomgyújtés, kéziratkészítés). A cikk végleges változatát valamennyi szerző elolvasta és jóváhagyta.

Érdekeltségek: A szerzőknek nincsenek érdekeltségeik.

\section{Irodalom}

[1] Dwijendra KS, Parikh V, George SS, et al. Association of dental anomalies with different types of malocclusions in pretreatment orthodontic patients. J Int Oral Health 2015; 7: 61-64.

[2] Pop SI, Mártha IK, Csibi R, et al. Objective evaluation of orthodontic treatment need with Dental Aesthetic Index. [Fogazati rendellenességek kezelési szükségletének tárgyilagos felmérése a Dental Aesthetic Index segítségével.] Orv Hetil. 2018; 159: 352-356. [Hungarian]

[3] Poosti M, Jalali T. Tooth size and arch dimension in uncrowded versus crowded Class I malocclusions. J Contemp Dent Pract. 2007; 8: 45-52.

[4] Bolton WA. The clinical application of a tooth-size analysis. Am J Orthod. 1962; 48: 504-529.

[5] DaCosta OO, Aikins EA, Isiekwe GI, et al. Malocclusion and early orthodontic treatment requirements in the mixed dentitions of a population of Nigerian children. J Orthod Sci. 2016; 5: 81-86.

[6] European Commission. Radiation Protection No. 162 - Criteria for acceptability of medical radiological equipment used in diagnostic radiology, nuclear medicine and radiotherapy. DirectorateGeneral for Energy, Directorate D - Nuclear Safety \& Fuel Cycle, Unit D4 - Radiation Protection, Luxembourg, 2012.

[7] Moyers RE. Handbook of orthodontics. 3rd edn. Year Book, Chicago, IL, 1973; pp. 369-379.

[8] Tanaka MM, Johnston LE. The prediction of the size of unerupted canines and premolars in a contemporary orthodontic population. J Am Dent Assoc. 1974; 88: 798-801.

[9] Gross A, Hasund A. New comparative correlation-statistical in vestigation for the prediction of the space requirements in the support zones by multiple regression equations. [Neuere vergleichende korrelationsstatistische Untersuchungen zur Vorhersage des Platzbedarfs in den Stützzonen durch multiple Regressionsgleichungen.] Fortschr Kieferorthop. 1989; 50: 109-117. [German]

[10] Bachmann S. Prediction of space requirements in the support zones using multiple regression equations. [Voraussage des Platzbedarfs in den Stützzonen mittels multipler Regressionsgleichungen.] Fortschr Kieferorthop. 1986; 47: 79-86. [German]

[11] Tränkmann J, Möhrmann G, Themm P. Comparative studies of the prognosis of supporting areas. [Vergleichende Untersuchungen der Stützzonenprognose.] Fortschr Kieferorthop. 1990; 51:189-194. [German]

[12] Legovic M, Novosel A, Legovic A. Regression equations for determining mesiodistal crown diameters of canines and premolars. Angle Orthod. 2003; 73: 314-318.

[13] Barrow GV, White JR. Developmental changes of the maxillary and mandibular dental arches. Angle Orthod. 1952; 22: 41-46.

[14] Hunter WS. Application of analysis of crowding and spacing of the teeth. Dent Clin North Am. 1978; 22: 563-577.

[15] Dewel BF. Serial extractions: their limitations and contra-indications in orthodontic treatment. 1. Ortodontia 1968; 1: 84-88.

[16] Hotz RP. Guidance of eruption versus serial extraction. Am J Orthod. 1970; 58: 1-20.

[17] Altherr ER, Koroluk LD, Phillips C. Influence of sex and ethnic tooth-size differences on mixed-dentition space analysis. Am J Orthod Dentofacial Orthop. 2007; 132: 332-339. 
[18] Lavelle CL. Maxillary and mandibular tooth size in different racial groups and in different occlusal categories. Am J Orthod. 1972; 61: 29-37.

[19] Bishara SE, Jakobsen JR, Abdallah EM, et al. Comparisons of mesiodistal and buccolingual crown dimensions of the permanent teeth in three populations from Egypt, Mexico, and the United States. Am J Orthod Dentofacial Orthop. 1989; 96: 416-422.

[20] Jaroontham J, Godfrey K. Mixed dentition space analysis in a Thai population. Eur J Orthod. 2000; 22: 127-134.

[21] Lee-Chan S, Jacobson BN, Chwa KH, et al. Mixed dentition analysis for Asian-Americans. Am J Orthod Dentofacial Orthop. 1998; 113: 293-299.

[22] Schirmer UR, Wiltshire WA. Orthodontic probability tables for black patients of African descent: mixed dentition analysis. Am J Orthod Dentofacial Orthop. 1997; 112: 545-551.

[23] Diagne F, Diop-Ba K, Ngom PI, et al. Mixed dentition analysis in a Senegalese population: elaboration of prediction tables. Am J Orthod Dentofacial Orthop. 2003; 124: 178-183.

[24] Ferguson FS, Macko DJ, Sonnenberg EM, et al. The use of regression constants in estimating tooth size in a Negro population. Am J Orthod. 1978; 73: 68-72.

[25] Garn SM, Lewis AB, Walenga A. Evidence for a secular trend in tooth size over two generations. J Dent Res. 1968; 47: 503.

[26] Lavelle CL. Secular trends in different racial groups. Angle Orthod. 1972 ; 42: 19-25.

[27] Harper C. A comparison of medieval and modern dentitions. Eur J Orthod. 1994; 16: 163-173.

[28] Galbany J, Dotras L, Alberts SC, et al. Tooth size variation related to age in Amboseli baboons. Folia Primatol. 2010; 81: 348-359.

[29] Murphy TR. Reduction of the dental arch by approximal attrition. A quantitative assessment. Br Dent J. 1964; 116: 483-488.

[30] Bernabé E, Villanueva KM, Flores-Mir C. Tooth width ratios in crowded and noncrowded dentitions. Angle Orthod. 2004; 74: 765-768.

[31] Hunter WS, Priest WR. Errors and discrepancies in measurement of tooth size. J Dent Res. 1960; 39: 405-414.
[32] Buwembo W, Luboga S. Moyer's method of mixed dentition analysis: a meta-analysis. Afr Health Sci. 2004; 4: 63-66.

[33] Yuen KK, Tang EL, So LL. Mixed dentition analysis for Hong Kong Chinese. Angle Orthod. 1998; 68: 21-28.

[34] Ling JY, Wong RW. Tanaka-Johnston mixed dentition analysis for southern Chinese in Hong Kong. Angle Orthod. 2006; 76: 632-636.

[35] Al-Bitar ZB, Al-Omari IK, Sonbol HN, et al. Mixed dentition analysis in a Jordanian population. Angle Orthod. 2008; 78: 670-675.

[36] Legovic M, Novosel A, Skrinjaric T, el al. A comparison of methods for predicting the size of unerupted permanent canines and premolars. Eur J Orthod. 2006; 28: 485-490.

[37] Dasgupta B, Zahir S. Comparison of two non-radiographic techniques of mixed dentition space analysis and evaluation of their reliability for Bengali population. Contemp Clin Dent. 2012; 3(Suppl 2): S146-150

[38] Mahmoud BK, Abu Asab SH, Taib H. Accuracy of four tooth size prediction methods on Malay population. ISRN Dent. 2012; 2012: 523703 .

[39] Ajayi EO. Regression equations and probability tables for mixed dentition analysis in a Nigerian population. J Dent Health Oral Disord Ther. 2014; 1: 00027.

[40] Philip NI, Prabhakar M, Arora D, et al. Applicability of the Moyers mixed dentition probability tables and new prediction aids for a contemporary population in India. Am J Orthod Dentofacial Orthop. 2010; 138: 339-345.

[41] Khan MI, Seedat AK, Hlongwa P. Tooth width predictions in a sample of Black South Africans. SADJ. 2007; 62: 244, 246-249.

[42] Paredes V, Tarazona B, Zamora N, et al. New regression equations for predicting human teeth sizes. Head Face Med. 2015; 11: 8. Doi: 10.1186/s13005-015-0067-8.

(Frank Dorottya dr., Pécs, Dischka Győző utca 5., 7621 e-mail: frank.dorottya@pte.hu)

\section{„Facile est imperium in bonis." (Plautus) (Könnyü a jók fölött uralkodni.)}

A cikk a Creative Commons Attribution 4.0 International License (https://creativecommons.org/licenses/by/4.0/) feltételei szerint publikált Open Access közlemény, melynek szellemében a cikk bármilyen médiumban szabadon felhasználható, megosztható és újraközölhetö, feltéve, hogy az eredeti szerző és a közlés helye, illetve a CC License linkje és az esetlegesen végrehajtott módosítások feltüntetésre kerülnek. (SID_1) 